\title{
ANALISIS PEMBERIAN FERMENTASI KULIT SINGKONG SEBAGAI PAKAN TAMBAHAN SAPI POTONG DI DESA WANAJAYA KECAMATAN WANARAJA KABUPATEN GARUT
}

\section{Analysis of the Utilization of Cassava Skin Fermentation as Additional Feed for Beef Cattle in Wanajaya Village, Wanaraja District Garut Regency}

\author{
Novi Desi Yana ${ }^{1 *}$, Harry ${ }^{2}$, Dyah Gandasari ${ }^{2}$ \\ ${ }^{1}$ Mahasiswa Jurusan Peternakan, Politeknik Pembangunan Pertanian Bogor \\ ${ }^{2}$ Dosen Jurusan Peternakan, Politeknik Pembangunan Pertanian Bogor \\ ${ }^{*}$ Korespondensi penulis, Email: novidesiyana6@gmail.com
}

Diterima: Juli 2020

Disetujui terbit: Oktober 2020

\begin{abstract}
Salma Jaya Farmers Group is one of the livestock groups located in the Village of Wanajaya Village, Wanaraja District, Garut Regency. This group has quite a lot of beef cattle and advanced, which is about 50 head. With such a large population, it is directly proportional to the abundance of cassava skin waste produced, such as tape waste and cassava chips. Unfortunately, the existence of cassava peel waste has not been used optimally, especially by members of the Salma Jaya farm group. Some farmers use cassava peels for free duck feed, some are even left to rot. The purpose of this study was to analyze the provision of cassava skin fermentation as an additional feed for beef cattle. Data collection procedures were carried out through pre-test and post-test. The analysis used in this study is using a paired $t$-test using statistical software (IBM SPSS Statistics 25). The results of research on the provision of cassava skin fermentation as an additional feed for beef cattle, namely: there was a difference in the increase in body weight of beef cattle between before and after the application of cassava skin fermentation.
\end{abstract}

Keywords: beef cattle, cassava peel, fermentation

\begin{abstract}
ABSTRAK
Kelompokternak Salma Jaya merupakan salah satu kelompokternak yang terletak di Desa Desa Wanajaya Kecamatan Wanaraja Kabupaten Garut. Kelompok ini memiliki ternak sapi potong yang cukup banyak dan maju yaitu sekitar 50 ekor. Dengan banyaknya populasi tersebut, berbanding lurus dengan melimpahnya limbah kulit singkong hasil produksi, seperti limbah tape dan keripik singkong. Namun sayangya, keberadaan limbah kulit singkong tersebut belum digunakan secara optimal, khususnya oleh anggota kelompokternak Salma Jaya. Beberapa petani menggunakan kulit singkong untuk pakan bebek secara cuma-cuma, bahkan ada yang dibiarkan begitu saja sampai membusuk. Tujuan penelitian yaitu menganalisis pemberian fermentasi kulit singkong sebagai pakan tambahan sapi potong. Prosedur pengumpulan data dilakukan melalui pre-test dan post-test. Analisis yang digunakan pada penelitian ini yaitu menggunakan uji t berpasangan dengan menggunakan piranti lunak statistik (IBM SPSS Statistics 25). Hasil penelitian pemberian fermentasi kulit singkong sebagai pakan tambahan sapi potong yaitu: terjadi perbedaan peningkatan bobot badan sapi potong antara sebelum dan sesudah dilakukannya kaji terap tentang fermentasi kulit singkong. Kata kunci: fermentasi, kulit singkong, sapi potong
\end{abstract}




\section{PENDAHULUAN}

Pembangunan pertanian yang dilaksanakan oleh pemerintah sangat penting untuk mensejahterakan komunitas pertanian. Salah satu perkembangan di bidang ekonomi rakyat adalah peningkatan di sektor peternakan, seperti peningkatan jumlah usaha yang terlibat di dalamnya, dan pembentukan lembaga kelompok tani ternak (Gandasari et al., 2020b).

Arah kebijakan umum
pengembangan sektor pertanian
diarahkan pada upaya peningkatan
produktivitas, produksi, dan nilai
tambah produk pertanian untuk
mendukung kebutuhan pangan
nasional, untuk memenuhi bahan
industri dan ekspor, dan untuk
memperluas peluang kerja dan
pendapatan para pelaku. Secara
umum, masalah utama dari sektor
pertanian adalah keanekaragaman,
kualitas, keberlanjutan pasokan, dan
kuantitas yang belum direalisasi
sesuai dengan dinamika permintaan
pasar (Gandasari et al., 2020a)
Pertumbuhan produksi daging
sapi (supply) di dalam negeri dari
tahun 2005-2013 terus meningkat,
namun belum mampu mengimbangi
laju permintaan (demand) yang
semakin meningkat, sehingga untuk

memenuhi permintaan tersebut diperlukan impor. Kebutuhan daging sapi secara nasional pada tahun 2013 sebesar 391 ribu ton, untuk penyediaannya dipenuhi dari produksi dalam negeri $(69,67 \%)$ dan impor (30,33\%). Impor daging sapi pada tahun 2013 cenderung naik bila dibandingkan dengan tahun 2012 yang hanya $21,29 \%$ dan berdasarkan angka sementara realisasi impor tahun 2014 (bulan Oktober) sudah mencapai 33,82\% (Ditjen PKH 2014 dalam Yuliana et al. 2014).

Keberhasilan usaha ternak sapi potong ditentukan oleh salah satu faktor terbesar, yaitu pakan. Pakan adalah semua yang bisa dimakan oleh ternak dan tidak mengganggu kesehtannya. Pada umumnya pengertian pakan (feed) digunakan untuk hewan yang meliputi kuantitatif, kualitatif, kontinuitas serta keseimbangan zat pakan yang terkandung di dalamnya (Anonim, 2011).

Kenyataannya, ditemukan kendala yang menjadi penghalang untuk keberhasilan tersebut. Komunikasi yang kurang memadai (Gandasari \& Musyadar, 2018) dan pengetahuan dan teknologi yang masih rendah (Gandasari et al. 2020a, 2020b). Hal ini berdampak pada 
rendahnya informasi dan pengetahuan tentang inovasi pemanfaatan limbah pertanian khususnya kulit singkong untuk pakan alternatif ternak.

Pemanfaatan limbah hasil olahan pothil berupa kulit singkong sebagai pakan sapi potong sudah menjadi kebiasaan bagi para peternak. Hal tersebut disebabkan karena sapi potong yang termasuk kedalam jenis ternak ruminansia mempunyai kemampuan mengkonversi bahan pakan yang mengandung serat kasar menjadi produk yang mendukung peningkatan performan dan produksi (Samadi et al. 2010 dalam Rahayu et al. 2019).

Hal itu memungkinkan kulit singkong memiliki kecernaan yang rendah serta dapat meracuni ternak. Kadar HCN yang mampu ditolerir ternak tidak boleh lebih dari 50 ppm. Teknik pengolahan seperti amoniasi dan fermentasi dapat meningkatkan kadar protein, kecernaan serta dapat menurunkan kadar $\mathrm{HCN}$ pada kulit singkong (Hanifah et al. 2010 dalam Simbolon et al. 2016). Beberapa penelitian menunjukkan bahwa kulit singkong memiliki kandungan protein dan serat kasar lebih tinggi dibandingkan singkong, kulit singkong kurang dapat dimanfaatkan sebagai bahan pakan ternak karena tingginya kandungan asam sianida ( $\mathrm{HCN})$ dan rendahnya kandungan protein bahan. Diharapkan dengan adanya fermentasi, maka kandungan protein bahan akan meningkat dan asam sianida dari kulit singkong dapat berkurang (Hastuti, 2012).

Pengamatan kandungan protein kasar bahan setelah fermentasi meningkat dibanding dengan sebelum fermentasi. Peningkatan protein kasar untuk kulit pisang dari 1,0\% menjadi $6,45 \%$ merupakan peningkatan yang cukup signifikan. Begitu pula dengan singkong yang meningkat dari 1,0\% menjadi $8,27 \%$. Hal ini disebabkan karena saat proses fermentasi berlangsung terjadi berlangsung terjadi proses kimia dan fisik terhadap bahan substrat (Akhadiarto, 2009).

\section{METODE PENELITIAN}

\section{Kerangka Berpikir}

Kegiatan kaji terap dimaksudkan untuk memberikan alternatif rekomendasi sekaligus meyakinkan peternak, serta berfungsi sebagai kegiatan demontrasi plot, karena membuktikan hasil dan cara yang dapat dilakukan oleh peternak.

\section{Metode, Lokasi dan Waktu Penelitian}

Metode yang dilakukan adalah pendekatan perorangan dan 
kelompok, demonstrasi cara dan hasil serta melakukan serangkaian yang berhubungan dengan kaji terap yang dilaksanakan. Tingkat penyerapan materi penyuluhan yang diberikan dapat diketahui lewat evaluasi pada bulan Mei. Pengukuran adopsi tingkat pengetahuan dilakukan evaluasi menggunakan kuesioner, sedangkan untuk mengukur tingkat keterampilan dan sikap dilakukan dengan menggunakan kuesioner lain.

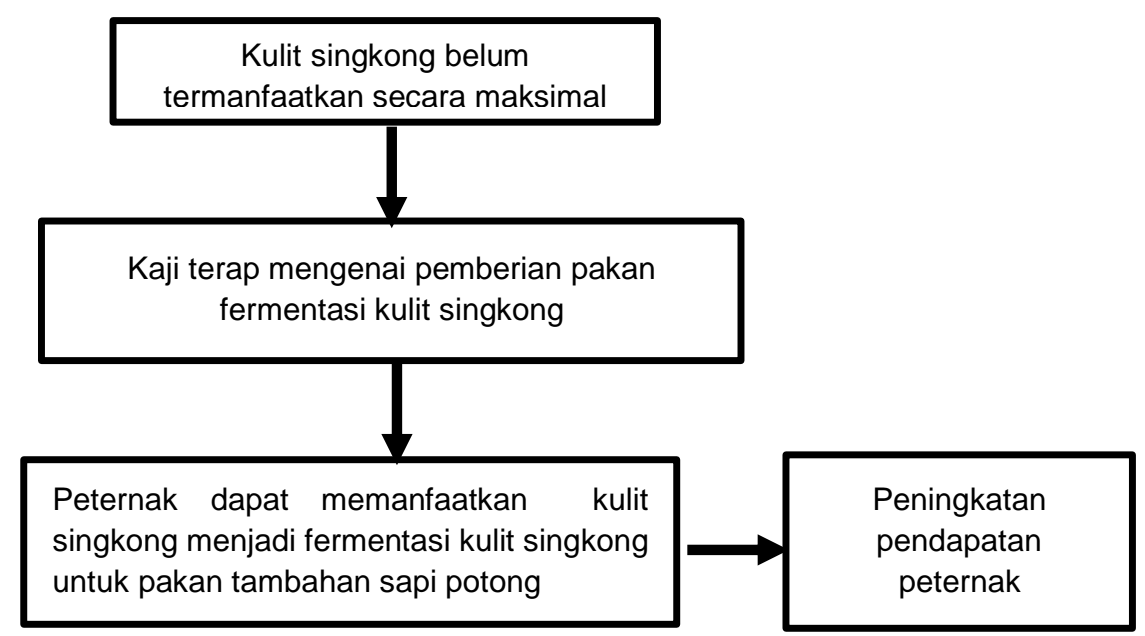

Gambar 1 Kaji terap mengenai pemanfaatan fermentasi kulit singkong

Penelitian dilaksanakan selama

4 bulan yaitu Mei-Juni 2020. Populasi pada pelaksanaan penelitian adalah anggota Kelompokternak Salma Jaya di Desa Wanajaya, Kecamatan Wanaraja. Pengambilan sampel dilakukan secara sampling jenuh (sensus). Sampling jenuh merupakan teknik pengambilan sampel dengan menggunakan seluruh anggota kelompokternak Salma Jaya yang mempunyai ternak sapi potong sebanyak 30 orang (lihat Tabel 2). Data yang digunakan dalam kajian ini ada dua macam yakni data primer dan data sekunder (Yashinta, 2018).
Pengumpulan data primer dilakukan pada kegiatan: survei/identifikasi masalah (wawancara); evaluasi awal (pre-test); kaji terap; evaluasi akhir (post-test). Pengumpulan data primer dilakukan pada responden yang merupakan anggota kelompokternak Salma Jaya. Data sekunder diperoleh dari Desa Wanajaya, Kecamatan Wanaraja dan Balai Penyuluhan Pertanian (BPP) Kecamatan Wanaraja. Data yang diperoleh meliputi: programa penyuluhan pertanian, monografi desa, dan populasi ternak. 
Tabel 1 Pengamatan pertama: Peningkatan protein dengan fermentasi padat

\begin{tabular}{lccc}
\hline \multicolumn{1}{c}{ Substrat } & $\begin{array}{c}\text { Protein Substrat } \\
(\%)\end{array}$ & $\begin{array}{c}\text { pH } \\
\text { Fermentasi }\end{array}$ & $\begin{array}{c}\text { Protein Produk } \\
(\%)\end{array}$ \\
\hline Kulit Singkong & 1,60 & 4,50 & 8,27 \\
Kulit Pisang & 1,00 & 4,48 & 6,45 \\
Kulit Kentang & 5,00 & 4,53 & 8,19 \\
\hline
\end{tabular}

Tabel 2 menunjukkan kepemilikan ternak yang mempunyai jumlah yang sedikit yaitu 3-9 ekor sebanyak 20 orang (67\%), jumlah ternak yang dimiliki oleh responden dipengaruhi karena peternak hanya memelihara sapi sebagai sampingan atau kebutuhan protein saja tidak sebagai pendapatan utama.

Fakta menunjukkan bahwa hasil uji perbedaan indikator variabel karakteristik peternak pada umumnya berbeda nyata, kecuali untuk indikator tingkat pendidikan formal, jumlah kepemilikan ternak, pengalaman dan kebutuhan tidak berbeda nyata. Itu karena pencapaian indikator relatif sama, oleh karena itu tidak menjadi perbedaan kinerja per kelas kelompok (Suwardi et al., 2020).

\section{Teknik Analisis Data}

Teknik analisis data adalah suatu cara yang dilakukan untuk mengolah data agar dihasilkan suatu kesimpulan yang tepat. Teknik ini menggunakan formulasi yang disesuaikan dengan tujuannya. Data yang diperoleh dianalisis dengan menggunakan analisis peningkatan bobot badan sapi adalah dengan menggunakan uji-t di Microsoft Excel (Sudjana, 2005).

Tabel 2 Karakteristik Responden Berdasarkan Kepemilikan Ternak

\begin{tabular}{cccc}
\hline No & Kepemilikan ternak & Jumlah (orang) & Presentase (\%) \\
\hline 1 & $3-9$ & 20 & 66,66 \\
2 & $10-16$ & 10 & 33,33 \\
3 & $17-23$ & 0 & 0 \\
4 & $24-30$ & 0 & 0 \\
5 & $31-37$ & 0 & 0 \\
6 & $>38$ & 0 & 0 \\
\hline Jumlah & & 30 & 100 \\
\hline
\end{tabular}

HASIL DAN PEMBAHASAN

Semua ternak sapi obat cacing Kalbazen-C diberikan secara oral dengan dosis $10 \mathrm{ml}$ setelah itu dilakukan penimbangan awal dan ini dilakukan sebelum kaji terap. Pelaksanaan kaji terap melibatkan anggota Kelompokternak Salma Jaya 
sebagai pemilik ternak sapi sekaligus sebagai pelaksana kaji terap. Pelaksanaan kaji terap dilakukan selama 40 hari. Ternak sapi yang digunakan adalah sapi jantan simental cross sebanyak 10 ekor usia 1-2 tahun.

Indikator yang diukur dalam pengkajian ini yaitu pertambahan bobot badan ternak dengan 3 perlakuan dan 5 ulangan. Adapun perlakuan yang dilakukan yaitu:

$$
\begin{aligned}
\mathrm{P} 0 & =20 \mathrm{~kg} \text { Jerami padi }+2,0 \mathrm{~kg} \\
& \text { konsentrat (ampas tahu } 1 \mathrm{~kg} \text {, dan } \\
& \text { dedak padi } 1 \mathrm{~kg}) \\
\mathrm{P} 1= & 20 \mathrm{~kg} \text { Jerami padi }+2,5 \mathrm{~kg} \\
& \text { konsentrat (ampas tahu } 1 \mathrm{~kg}, \\
& \text { dedak padi } 1 \mathrm{~kg}+\text { fermentasi kulit } \\
& \text { singkong } 500 \mathrm{~g}) \\
\mathrm{U}= & \text { ulangan }
\end{aligned}
$$

Berdasarkan hasil penimbangan yang dilakukan awal dan pada akhir kaji terap dapat dilihat pada Tabel 3.

Tabel 3 Hasil penimbangan sapi potong kaji terap selama 40 hari

\begin{tabular}{lccccc}
\hline Perlakuan & $\begin{array}{c}\text { Berat Awal } \\
\mathbf{( k g )}\end{array}$ & $\begin{array}{c}\text { Berat Akhir } \\
\mathbf{( k g )}\end{array}$ & $\begin{array}{c}\text { PBB } \\
(\mathbf{k g})\end{array}$ & $\begin{array}{c}\text { PBBH } \\
(\mathbf{k g})\end{array}$ & PBBH (g) \\
\hline P0 & $361,60 \pm 42,05$ & $387,60 \pm 41,52$ & $26 \pm 0,71$ & $0,65 \pm 0,02^{\mathrm{b}}$ & $650 \pm 17,68$ \\
P1 & $244,40 \pm 10,19$ & $276,4 \pm 8,17$ & $32 \pm 2,74$ & $0,79 \pm 0,08^{\mathrm{a}}$ & $795 \pm 75,83$
\end{tabular}

Keterangan: Huruf kecil berbeda menunjukkan perbedaan pada signifikansi $(\alpha, 0,05)$ hasil ujit tidak berpasangan

Tabel 3 menyatakan bahwa terdapat perbedaan peningkatan BB sapi potong sebagai berikut:

a. $P 0=20 \mathrm{Kg}$ jerami padi $+2,0 \mathrm{~kg}$ konsentrat (ampas tahu $1 \mathrm{~kg}$, dan dedak padi $1 \mathrm{~kg}$ ), BB sapi potong sebesar 650 gram/ekor/hari.

b. $P 1=20 \mathrm{~kg}$ jerami padi $+2,5 \mathrm{~kg}$ konsentrat (ampas tahu $1 \mathrm{~kg}$, dedak padi $1 \mathrm{~kg}+$ fermentasi kulit singkong 500 gram), BB sapi potong sebesar 795 gram/ekor/hari.

Adanya perbedaan peningkatan pertambahan bobot badan harian $(\mathrm{PBBH})$ antara perlakuan $\mathrm{PO}$ dan perlakuan P1 disebabkan karena adanya perbedaan pemberian dosis pakan dan inovasi pakan yang diberikan.

Berdasarkan perhitungan tersebut, pada tingkat kepercayaan 95 $\%$ dapat dilihat bahwa $t$ hitung $(4,31)>$ t tabel (2,306). Artinya, pemberian pakan fermentasi kulit singkong sebanyak 500 gram berpengaruh sangat nyata terhadap peningkatan bobot badan sapi potong jantan Simmental cross. 


\section{SIMPULAN DAN SARAN}

\section{Simpulan}

Keberhasilan usaha ternak sapi potong ditentukan oleh salah satu faktor terbesar, yaitu pakan. Rendahnya pemanfaatan limbah pertanian khususnya kulit singkong untuk pakan alternatif ternak menjadi faktor penting untuk penerapan inovasi. Salah satu inovasi yang digunakan yaitu fermentasi.

Berdasarkan penelitian dilapangan mengenai pemanfaatan fermentasi kulit singkong untuk pakan alternatif sapi potong, menunjukkan adanya dampak yang bagus terhadap pertambahan bobot badan sapi potong dengan rata-rata 795 gram/ekor/hari. Inovasi tersebut bisa menjadi contoh keberhasilan dalam pemanfaatan inovasi yang cukup mudah dikalangan petani ternak.

\section{Saran}

Untuk meningkatkan sektor
pertanian khususnya bidang
peternakan, diperlukan sumberdaya
alam dan sumberdaya manusia yang
baik dan berkualitas. Dukungan
tersebut tidak terlepas dari peran
pemerintah, serta penyuluh pertanian
yang berfungsi sebagai pembawa
informasi untuk disampaikan kepada
petani ternak.

\section{DAFTAR PUSTAKA}

Akhadiarto S. 2009. Pemanfaatan Limbah Kulit Singkong, Kulit Pisang dan Kulit Kentang Sebagai Bahan Pakan Ternak Melalui Teknik Fermentasi. J Tek. Ling. Vol.10 No.3 Hal. 257 -263 .

Gandasari D, Musyadar A. 2017. Informasi Budidaya dalam Jaringan Komunikasi Petani Cabai. Jurnal Penyuluhan Pertanian. Vol 12(2).

Gandasari D, Suwardi S, Wihansah RRS, Wardani, Taopik AO, 2020a. Analysis of Agribusiness Communication Network among Beef Cattle Farmers: Case Study at Sarimulya Mandiri as The Beginner's Farmers Group. Vol 29(03) : 5339 - 5347.

Gandasari D, Sugandi A, Wihansah RRS, Wardani, Suwardi S. 2020b. Sociometry Analysis of Beef Cattle Farmers Institution in Indonesia: Case of Bina Insani as an Advanced Farmers Group. International Journal of Advanced Science and Technology. Vol 29 (03) : 5375 $-5385$. 
Hastuti S. 2012. Fermentasi Kulit Singkong Dengan Ragi Komersial Untuk Peningkatan Nilai Gizi. Jurnal Rekayasa. Vol 5(1) April.

Rahayu PT, Viana NDC, Luklukyah Z, Irawan B. 2019. Potensi Daya Dukung Kulit Singkong Olahan Pothil Sebagai Pakan Sapi Potong Dalam Potensi Daya Dukung Limbah Kulit Singkong hasil Olahan Pothil sebagai Pakan Sapi Potong di Kecamatan Dukun, Magelang. Jawa Tengah. Bulletin of Applied Animal Research. Vol 1(2):1-4.

Simbolon N, Pujaningsih IR, Mukodiningsih S. 2016. Pengaruh Berbagai Pengolahan Kulit Singkong Terhadap Kecernaan Bahan Kering dan Bahan Organik Secara In Vitro, Protein Kasar Dan Asam Sianida. Jurnal IImu-IImu Peternakan. Vol. 26 (1): 58 - 65. Sudjana. 2005. Metode Statistika. Edisi ke-6. Bandung: Tarsito.

Suwardi S, Gandasari D, Taopik AO, Wardani, Wihansah RRS. 2020. Critical Dimension on Beef Cattle Livestosk Institutional Development (A Case of Social-
Economic Engineering on Learning Society). Vol. 29 (03): $8123-8129$.

Yashinta H. 2018. Penyuluhan Tentang Fungsi Kelompoktani dan Agribisnis Domba Di Desa Selasari Kecamatan Parigi Kabupaten Pangandaran. Laporan. Bogor: Sekolah Tinggi Penyuluhan Pertanian Bogor.

Yuliana S, Dominicus PS, Mulatsih S. 2014.

Penembangan Peternakan Sapi Potong Untuk Peningkatan Perekonomian Provinsi Jawa Tengah: Suatu Pendekatan Perencanaan Wilayah. Jurnal Agribisnis Indonesia. Vol. 2 (2): 177-190. 